\title{
LAMA MASA KERJA DAN TINGKAT PENDIDIKAN PERAWAT DENGAN PENANGANAN PERTAMA KEJANG DEMAM PADA ANAK
}

\author{
Karmela Grace Tambariki $^{1}$, Lucky T. Kumaat ${ }^{2}$, Wico N. Silolonga ${ }^{3}$
}

1. Mahasiswa Program Studi Ilmu Keperawatan, Fakultas Kedokteran, Universitas Sam Ratulangi, Indonesia

2. Fakultas Kedokteran, Universitas Sam Ratulangi, Indonesia

3. Puskesmas Tinoor Tomohon, Indonesia

Email : karmelagt@gmail.com

\begin{abstract}
Abstrak
Kejang demam yang berlangsung lama (>15 menit) biasanya disertai apnea sehingga dapat menyebabkan terjadinya kerusakan neuron otak. 2-10\% dapat berkembang menjadi epilepsi. Kejang demam pada anak yang satu dengan yang lain tidaklah sama tergantung pada nilai ambang kejang masing-masing. Oleh karena itu, ketika serangan kejang demam terjadi maka harus di tangani secara cepat dan tepat. Tujuan penelitian ini untuk mengetahui hubungan lama masa kerja dan tingkat pendidikan perawat dengan penanganan pertama kejang demam pada anak. Metode penelitian ini menggunakan desain penelitian analitik korelasi, dengan pendekatan retrospektif. Sampel penelitian menggunakan metode total sampling, dan didapatkan sampel dengan jumlah sebanyak 31 responden. Hasil penelitian dengan menggunakan uji spearmen, pada tingkat kemaknaan 95\%, signfikan untuk lama masa kerja dengan penanganan pertama kejang demam (nilai $\mathrm{p}: 0,275>0,05$ ) dan signifikan tingkat pendidikan dengan penanganan pertama kejang demam pada anak (nilai $\mathrm{p}: 0,335>0,05$ ). Kesimpulan tidak terdapat hubungan yang signifikan antar lama masa kerja dan tingkat pendidikan perawat dengan penanganan pertama kejang demam pada anak di IGD RSU GMIM Bethesda Tomohon dan RS Bhayangkara TK III Manado.
\end{abstract}

Kata kunci : Lama masa kerja, Tingkat Pendidikan, Penanganan pertama kerjang demam

\begin{abstract}
Febrile seizures that last for more than 15 miutes by usually accompanied apanea so that it can cause damage to brain neurons. 2-10\% can develop into epilepsy. Febrile seizures in one child with another are not the same depending on the value of each seizure threshold. Therefore, when a febrile seizure attack occurs, it must be dealt with quickly and appropriately. The purpose of this study was to determine the relationship between length of work and nurse education level with the first treatment of febrile seizures in children. Method uses a correlation analytic research design, with a retrospective approach. The research sample uses a total sampling method, and obtained a sample of 31 respondents. Results of the study used the spearmen test, at a significance level of $95 \%$, were significant for the length of work with the first treatment of febrile seizures ( $\mathrm{p}$ value : $0.275>0.05$ ) and significant levels of education with the first treatment of febrile seizures in children ( $p$ value : $0.335>0.05$ ). Conclusion there is no significant relationship between the length of work and the education level of nurses with the first treatment of febrile seizures in children in the emergency room GMIM General Hospital Bethesda Tomohon and Hospital Bhayangkara TK III Manado.
\end{abstract}

Keywords : Length of work, Education Level, First handling fever work. 


\section{PENDAHULUAN}

Kejang merupakan salah satu hal yang dapat mempengaruhi perkembangan anak pada kejadian tertentu terutama pada kejang yang berlangsung lama (>15 menit) biasanya disertai dengan apnea sehingga dapat terjadi hipoksia yaitu kekurangan oksigen dalam jaringan. Keadaan ini merupakan salah satu proses terjadinya kerusakan neuron otak (Kusuma, 2010). Sehingga apabila anak mengalami kejang yang lama, kejang berulang atau sering kejang maka akan semakin banyak sel otak yang mengalami kerusakan dan mempunyai resiko yang dapat menyebabkan kecacatan otak pada anak atau keterbelakangan mental bahkan kematian, dan 2-10\% dapat berkembang menjadi epilepsi (Mohammadi, 2010).

Berdasarkan pembahasan dalam buku Lestari (2016) dikatakan bahwa pertolongan pertama atau penanganan keperawatan yang seharusnya dilakukan pada pasien saat terjadi kejang ialah memiringkan posisi pasien untuk menghindari aspirasi ludah atau muntahan, dan jika pasien menggunakan pakaian yang ketat sebaiknya dibuka agar jalan nafasnya bebas dan oksigenasi terjamin. Pantau keadaan vital pasien seperti suhu, kesadaran, pernapasan, tekanan darah, dan fungsi jantung. Diazepam dapat diberikan secara intrarektal setiap 8 jam sebanyak 5 $\mathrm{mg}(\mathrm{BB}>10 \mathrm{~kg})$ dan $10 \mathrm{mg}(\mathrm{BB}>10 \mathrm{~kg})$ ketika pasien menunjukkan suhu $>38,5^{\circ} \mathrm{C}$. Berdasarkan salah satu pengalaman dari peneliti sendiri ketika sedang menjalankankan tugas praktik kuliah disebuah rumah sakit dan mengamati bagaimana cara petugas kesehatan dalam menganalisa dan menanganani pasien kejang demam anak didapati bahwa ketika ada pasien anak balita yang datang ke IGD tersebut diperiksa dengan kondisi demam $38^{\circ} \mathrm{C}$ dengan penurunan kesadaran, tetapi petugas kesehatan hanya memeriksa suhu anak tesebut dan belum melakukan pencegahan atau penanganan awal apapun. Petugas kesehatan di IGD tersebut baru melakukan monitor kembali ketika pasien tersebut mulai mengalami manifetasi kejang demam. Ketika mereka mempersiapkan segala sesuatu untuk penanganan terlihat saat menangani pasien dengan kejang demam seperti kurang persiapan sehingga kelengkapan alat-alat yang diperlukan untuk penanganan harus diambil secara berulang.

Menurut hasil penelitian Arifudin (2016) mengatakan bahwa anak yang memiliki suhu tubuh yang tinggi atau lebih dari $37,8^{\circ} \mathrm{C}$ berisiko lebih besar untuk mengalami kejang demam. Hal ini didukung oleh teori yang mengatakan bahwa demam merupakan salah satu faktor pemicu utama terjadinya kejang demam. Tingginya suhu tubuh pada saat timbul kejang merupakan nilai ambang kejang. Setiap anak memiliki nilai ambang kejang yang berbeda-beda, berkisar antara $38,3^{\circ} \mathrm{C}$ - 41, $4^{\circ} \mathrm{C}$. Perbedaan ini menggambarkan bahwa ada anak yang ketika suhu tubuhnya meningkat sangat tinggi baru mengalami kejang tetapi ada juga anak yang mengalami kejang demam walaupun suhu tubuhnya meningkat tidak terlalu tinggi.

Dalam hal ini perawat merupakan salah satu tenaga kesehatan yang sudah seharusnya dapat berperan aktif untuk mengatasi hal tersebut dan memberikan asuhan keperawatan kepada pasien dan keluarga yang meliputi aspek promotif, preventif, kuratif dan rehabilitatif secara terpadu dan berkesinambungan serta memandang klien sebagai satu kesatuan yang utuh (Mawu, Bidjuni, Hamel, 2016). Jika terjadi keterlambatan dan kesalahan prosedur utamanya pada kasus kejang demam pada anak maka kemungkinan bisa menyebabkan gejala sisa pada anak dan bahkan bisa menyebabkan kematian (Khasana, 2013). Dalam penelitian yang dilakukan oleh Koesrini (2016) mengenai hubungan pengetahuan perawat tentang kejang demam dengan penanganannya didapatkan hasil bahwa terdapat hubungan antara kedua variabel tersebut dan salah satu hal dominan yang 
melatarbelakanginya yaitu lama kerja perawat. Semakin lama perawat bekerja maka pengetahuan dalam penanganan kejang semakin baik. Tetapi dalam penelitiannya pula masih didapatkan perawat yang walaupun telah lama bekerja tapi memiliki pengetahuan penanganan kejang yang cukup saja karena dilatarbelakangi oleh beban kerja yang terlalu banyak, perbandingan jumlah pasien dengan perawat yang yang kurang ideal serta adanya masalah psikologi dan motivasi.

Menurut studi pendahuluan yang peneliti lakukan di Instalasi Gawat Darurat Rumah Sakit Umum Gereja Masehi Injili Minahasa Bethesda Tomohon, yang mengalami demam setiap bulannya sekitar 50 orang pada tahun 2018 dan yang mengalami serangan kejang demam pada 3 bulan terakhir tahun 2019 sekitar 22 orang anak. Jumlah perawat yang bertugas di ruangan tersebut ialah 19 orang, dengan jadwal tugas pershif yaitu 4 orang perawat. Selanjutnya saya juga melakukan studi pendahuluan di IGD RS Bhayangkara Manado, dan pasien yang mengalami demam setiap bulannya kurang lebih sekitar 40 orang tahun 2018 dan dalam 3 bulan terakhir tahun 2019 terdapat kurang lebih 18 orang yang mengalami kejang demam dan jumlah perawat yang bertugas di IGD ialah 16 orang dengan jadwal pershift yaitu 4 orang perawat.

Berdasarkan uraian diatas, maka penulis merasa tertarik untuk mengetahui lebih lanjut dan melakukan penelitian dengan judul "Hubungan Lama Masa Kerja dan Tingkat Pendidikan Perawat Dengan Penanganan Pertama Kejang Demam Pada Anak di RSU GMIM Bethesda Tomohon dan RS Bhayangkara TK III Manado". Sebelumnya pernah dilakukan penelitian mengenai "Hubungan pengetahuan perawat tentang kejang demam dengan penanganan kejang demam pada anak di Instalasi Rawat Darurat Anak (IRDA) dan Ruang Perawatan Intensif (RPI) Irina E RSUP Prof.Dr.R.D.Kandou
Manado oleh Herman Rama Putra (2014). Tetapi yang membedakan kali ini ialah peneliti melakukan penelitian di instalasi gawat darurat dengan sampel yang diambil pada dua rumah sakit dengan tipe yang berbeda dari penelitian sebelumnya.

\section{METODE PENELITIAN}

Jenis penelitian ini yaitu analitik korelasi dengan pendekatan retrospektif dimana peneliti telah meneliti kembali bagaimana pengalaman penanganan perawat pada pasien kejang demam terutama pada anak. Penelitian ini adalah untuk mengetahui Hubungan lama masa kerja dan tingkat pendidikan perawat dengan penanganan pertama kejang demam pada anak di IGD RSU GMIM Bethesda Tomohon dan RS Bhayangkara TK III Manado. Lokasi penelitian di lakukan di Ruang IGD RSU GMIM Bethesda Tomohon dan RS Bhayangkara TK III Manado. Penelitian ini pada tahap persiapan sampai pelaporannya di laksanakan selama bulan Juli-November 2019.

Populasi pada penelitian ini yaitu perawat yang berada di Ruang IGD RSU GMIM Bethesda Tomohon dengan jumlah 19 orang dan RS Bhayangkara TK III Manado dengan jumlah 16 orang. Sampel dalam penelitian ini menggunakan total populasi yang memenuhi kriteria inklusi, yaitu sebanyak 31 responden. Pada penelitian ini menggunakan lembar isi karakteristik perawat dan kuesioner penanganan pertama pada pasien kejang demam. Karakteristik perawat menggunakan lembar isian yang sudah pernah digunakan oleh Daniel Piter Mawu (2016), yang meliputi : Umur, Jenis kelamim, tingkat pendidikan, lama masa kerja di ruang IGD. Penanganan kejang demam akan menggunakan kuesioner yang diadopsi dari salah satu kuesioner penelitian yang sudah pernah digunakan oleh Herman Rama Putra (2014), dengan pengukuran menggunakan skala likert yaitu Tidak Setuju (TS), Kurang Setuju 
(KS), Setuju (S), Sangat Setuju (SS). Jika responden memilih Tidak Setuju (TS) akan diberi skor 1, Kurang Setuju (KS) diberi skor 2, Setuju (S) diberi skor 3, Sangat Setuju (SS) diberi skor 4. Jumlah poin 15$30=$ kurang, $31-45=$ cukup, $46-60=$ baik. Hasil uji validitas menunjukkan ada 15 pertanyaan yang memiliki nilai $r$ hasil $>r$ tabel dinyatakan valid dan 5 pertanyaan yang memiliki nilai $\mathrm{r}<\mathrm{r}$ tabel dinyatakan tidak valid. 15 pertanyaan yang sudah valid, analisis dilanjutkan dengan uji reliabilitas, dari hasil uji tersebut nilai $\mathrm{r}$ Alpha $(0,932)>\mathrm{r}$ hasil $(0,444)$, maka 15 pertanyaan tersebut dinyatakan reliable. Pengolahan data melalui tahap editing, coding, cleaning dan processing. Data dianalisa melalui analisis univariat dan bivariat dengan menggunakan uji spearmen dengan tingkat kemaknaan $95 \%$ $(\alpha=0,05)$ untuk melihat hubungan antara lama masa kerja dan tingkat pendidikan perawat dengan penanganang pertama kejang demam pada anak.

Penelitian ini telah dilakukan dengan standart etika penelitian yang ada yaitu memberikan lembar persetujuan (informed consent) kepada responden yang akan diteliti yang memenuhi kriteria inklusi agar subjek penelitian mengetahui maksud dan tujuan peneliti, tidak mencantumkan nama responden namun hanya menggunakan nama inisial (Anonymity) dan menghormati privasi dan kerahasiaan responen (Confidentiality). Penelitian telah mendapat izin dari RSU GMIM Bethesda Tomohon dengan nomor surat : 538-U/02/IX/2019 dan RS Bhayangkara TK III Manado dengan nomor surat : 07SK/IX/YAN.2.4./2019

\section{HASIL dan PEMBAHASAN}

\section{Karakteristik responden}

Tabel 1. Distribusi Frekuensi Responden Berdasarkan Usia

\begin{tabular}{ccc}
\hline Usia & n & \% \\
\hline $17-25$ & 11 & 35,5 \\
$26-35$ & 18 & 58,1 \\
$36-45$ & 2 & 6,5 \\
Total & 31 & 100 \\
\hline
\end{tabular}

Sumber : Data Primer, 2019

Distribusi frekuensi berdasarkan usia pada tabel 1 menunjukkan bahwa dari 31 responden, terbanyak responden dengan usia 26-35 tahun (dewasa awal) yaitu sebanyak 18 perawat $(58,1 \%)$. Menurut
Kumbadewi (2016) usia produktif seorang pekerja berada dalam rentang 15 sampai 65 tahun sehingga dapat dikatakan bahwa responden dalam penelitian ini memiliki usia produktif.

Tabel 2. Distribsi Frekuensi Responden Berdasarkan Jenis Kelamin

\begin{tabular}{ccc}
\hline Jenis Kelamin & n & \% \\
\hline Laki-laki & 13 & 41,9 \\
Perempuan & 18 & 58,1 \\
Total & 31 & 100 \\
\hline
\end{tabular}

Sumber : Data Primer, 2019

Distribusi frekuensi berdasarkan tabel 2 menunjukkan bahwa dari 31 responden, terbanyak responden dengan jenis kelamin perempuan dengan jumlah 18 perawat $(58,1 \%)$. Hasil penelitian sebelumnya yang dilakukan oleh Mawu 
(2016) tentang hubungan karakteristik dengan penanganan pertama pada pasien kegawatan musculoskeletal didapatkan bahwa kebanyakan responden berjenis kelamin perempuan dengan presentase 74,5\%. Menurut Manorek (2018) secara psikologi, perempuan merupakan seseorang yang memiliki sifat atau naluri keibuan yang dibutuhkan dalam melayani, sehingga diharapkan sifat perawat perempuan bisa lebih sabar dan perhatian dalam memberikan pelayanan khususnya dalam pelayanan kesehatan.

\section{Analisa Univariat}

Tabel 3. Distribusi Frekuensi Responden Berdasarkan Lama Masa Kerja

\begin{tabular}{ccc}
\hline Lama Masa Kerja & $\mathbf{n}$ & $\mathbf{\%}$ \\
\hline$<3$ Tahun & 13 & 41,9 \\
$>3$ Tahun & 18 & 58,1 \\
Total & 31 & 100 \\
\hline
\end{tabular}

Sumber : Data Primer, 2019

Distribusi frekuensi berdasarkan tabel 3 menunjukkan bahwa dari 31 responden, lama bekerja lebih dari 3 tahun paling banyak dengan jumlah 18 perawat (58,1\%). Hasil penelitian Putra (2014) tentang hubungan pengetahuan perawat dengan penanganan pertama kejang demam didapatkan bahwa kebanyakan responden adalah mereka yang sudah lama bekerja lebih dari tiga tahun dengan presentase 53,3\%. Menurut Manorek (2018), lama bekerja dapat mempengaruhi kinerja seseorang. Semakin lama bekerja maka akan semakin tinggi juga tingkat kedewasaannya dalam mengelola setiap masalah yang terjadi di tempat kerja.

Tabel 4. Distribusi Frekuensi Responden Berdasarkan Tingkat Pendidikan

\begin{tabular}{ccc}
\hline Tingkat Pendidikan & n & \% \\
\hline AKPER/D-III Keperawatan & 20 & 64,5 \\
S1.Keperawatan & 11 & 35,5 \\
Total & 31 & 100 \\
\hline
\end{tabular}

Sumber : Data Primer, 2019

Distribusi frekuensi berdasarkan tabel 4 menunjukkan bahwa paling banyak responden memiliki pendidikan AKPER/D-III Keperawatan yaitu sebanyak 20 perawat. Menurut renoningsih (2016), kemampuan seorang perawat dapat dipengaruhi oleh tingkat pendidikannya.
Pendidikan yang tinggi dapat meningkatkan kematangan intelektual seseorang sehingga pengetahuan yang dimiliki dapat dikembangkan bahkan diterapkan dalam bidang pelayanan kesehatan. 
Tabel 5. Distribusi Frekuensi Responden Berdasarkan Penanganan Kejang Demam

\begin{tabular}{ccc}
\hline Penanganan Kejang Demam & n & \% \\
\hline Cukup & 8 & 25,8 \\
Baik & 23 & 74,2 \\
Total & 31 & 100 \\
\hline
\end{tabular}

Sumber : Data Primer, 2019

Tabel 5.5 menunjukkan bahwa penanganan kejang demam oleh responden paling banyak tergolong baik sebanyak 23 perawat. Dalam penelitian yang dilakukan oleh Koesrini (2015) tentang hubungan pengetahuan perawat tentang kejang demam dengan penanganannya memaparkan bahwa sebagian besar perawat yang diteliti berada pada kategori penanganan yang baik dengan presentase $50 \%$ dengan sebagian lainnya berada pada kategori cukup baik dan kurang baik. Dalam penelitian yang dilakukan oleh Mamahit (2015) mengenai hubungan pengetahuan perawat dan dukungan keluarga dengan penatalaksanaan kejang demam pada anak memaparkan bahwa terdapat hubungan antar kedua variabel tersebut. Dan hal itu didukung oleh wawasan dan pengalaman perawat ketika bekerja serta berinteraksi dengan tim kerja.

\section{Analisa Bivariat}

Tabel 6. Analisis Hubungan Antar Lama Masa Kerja dengan Penanganan Pertama Kejang Demam

\begin{tabular}{|c|c|c|c|c|c|c|c|c|}
\hline \multirow{3}{*}{$\begin{array}{c}\text { Lama Masa } \\
\text { Kerja }\end{array}$} & \multicolumn{6}{|c|}{$\begin{array}{l}\text { Penanganan Kejang Demam } \\
\end{array}$} & \multirow{3}{*}{$\begin{array}{c}P \\
\text { value }\end{array}$} & \multirow{3}{*}{$\begin{array}{l}\text { Koefisen } \\
\text { Korelasi }\end{array}$} \\
\hline & \multicolumn{2}{|c|}{ Cukup } & \multicolumn{2}{|c|}{ Baik } & \multicolumn{2}{|c|}{ Total } & & \\
\hline & $\mathbf{n}$ & $\%$ & $\mathbf{n}$ & $\%$ & $\mathbf{n}$ & $\%$ & & \\
\hline$<3$ Tahun & 2 & 10,5 & 11 & 27,8 & 13 & 38,3 & & \\
\hline$>3$ Tahun & 6 & 31,4 & 12 & 30,3 & 18 & 61,7 & 0.275 & $-0,202$ \\
\hline Total & 8 & 41,9 & 23 & 58,1 & 31 & 100 & & \\
\hline
\end{tabular}

Analisis hubungan antara lama masa kerja perawat dengan penanganan pertama kejang demam pada anak pada berdasarkan tabel 6 menunjukkan bahwa responden yang bekerja $<3$ tahun paling banyak berada pada kategori baik dalam penanganan kejang demam dengan responden sebanyak 11 perawat. Pada responden yang bekerja > 3 tahun paling banyak pula berada pada kategori baik dengan jumlah 12 perawat. Hasil akhir dari analisis menggunakan Spearmen didapatkan angka koefisien korelasi sebesar -0,202. Angka koefisien korelasi yang ada bernilai negative yang berarti lama masa kerja perawat tidak searah dengan kinerja atau penanganan kejang yang baik. Untuk korelasi lama masa kerja dengan penanganan pertama perawat pada kejang demam anak didapatkan angka probabilitas $\mathrm{p}$ value sebesar 0,275 yang berarti bahwa nilai $p$ value $(0,275) \geq 0,05$. Dengan demikian dapat disimpulkan bahwa Ha ditolak dan H0 diterima, yaitu tidak tedapat hubungan yang signifikan antara lama masa kerja dengan penanganan pertama kejang demam pada anak di IGD RSU GMIM Bethesda Tomohon dan RS Bhayangkara TK III Manado.

Dalam penelitian yang dilakukan oleh Koesrini (2016) mengenai hubungan pengetahuan perawat tentang kejang demam dengan penanganannya didapatkan hasil bahwa terdapat hubungan antara kedua variabel tersebut dan salah satu hal 
dominan yang melatarbelakanginya yaitu lama kerja perawat. Tetapi dalam penelitiannya pula masih didapatkan perawat yang walaupun telah lama bekerja tapi memiliki pengetahuan penanganan kejang yang cukup saja karena dilatarbelakangi oleh beban kerja yang terlalu banyak, perbandingan jumlah pasien dengan perawat yang yang kurang ideal serta adanya masalah psikologi dan motivasi kerja. Hal ini didukung oleh penelitian yang dilakukan oleh Nazvia (2014) menyatakan pula bahwa tidak terdapat hubungan antar lama kerja perawat dengan kepatuhan melaksanakan SOP Asuhan keperawatan di ICU-ICCU RSUD Gambira kota Kediri karena dipengaruhi oleh motivasi yang rendah dalam melaksanakannya. Hal ini sejalan dengan penelitian yang dilakukan oleh Makta (2013) mengenai pengaruh motivasi kerja dengan kinerja perawat menyatakan bahwa motivasi kerja (prestasi, kondisi kerja, gaji, hubungan antar pribadi, supervise) berpengaruh terhadap kinerja perawat.

Tabel 7. Analisis Hubungan Tingkat Pendidikan dengan Penanganan Kejang Demam

\begin{tabular}{|c|c|c|c|c|c|c|c|c|}
\hline \multirow{3}{*}{ Pendidikan } & \multicolumn{6}{|c|}{ Penanganan Kejang Demam } & \multirow{3}{*}{ P value } & \multirow{3}{*}{$\begin{array}{l}\text { Koefisen } \\
\text { Korelasi }\end{array}$} \\
\hline & \multicolumn{2}{|c|}{ Cukup } & \multicolumn{2}{|c|}{ Baik } & \multicolumn{2}{|c|}{ Total } & & \\
\hline & $\mathbf{n}$ & $\%$ & $\mathbf{n}$ & $\%$ & $\mathbf{n}$ & $\%$ & & \\
\hline AKPER/D-III & 4 & 32,25 & 16 & 24,7 & 20 & 56,95 & & \\
\hline Keperawatan & & & & & & & 0,335 & -179 \\
\hline S1.Keperawatan & 4 & 32,25 & 7 & 10,80 & 11 & 43,05 & & \\
\hline Total & 8 & 64,5 & 23 & 35,5 & 31 & 100 & & \\
\hline
\end{tabular}

Sumber : Data Primer, 2019

Analisis hubungan antara tingkat pendidikan perawat dengan penanganan pertama kejang demam pada anak berdasarkan tabel 7 menunjukkan bahwa responden yang memiliki tingkat pendidikan DIII keperawatan paling banyak berada pada kategori baik dalam penanganan kejang demam dengan responden sebanyak 16 perawat. Pada responden yang memiliki tingkat pendidikan S1 keperawatan paling banyak pula berada pada kategori baik dengan jumlah 7 perawat. Hasil akhir dari analisis menggunakan Spearmen didapatkan angka koefisien korelasi sebesar -0,179. Angka koefisien korelasi bernilai negativ, yang berarti tingkat pendidikan perawat tidak searah dengan penanganan kejang demam yang baik. Untuk korelasi tingkat pendidikan dengan penanganan pertama perawat pada kejang demam anak didapatkan angka probabilitas $\mathrm{p}$ value sebesar 0,335 yang berarti bahwa nilai $p$ value $(0,335) \geq 0,05$. Dengan demikian dapat disimpulkan bahwa Ha ditolak dan
H0 diterima, yaitu tidak tedapat hubungan yang signifikan antara lama masa kerja dengan penanganan pertama kejang demam pada anak di IGD RSU GMIM Bethesda Tomohon dan RS Bhayangkara TK III Manado.

Dalam penelitian yang dilakukan oleh Rizal (2017) mengenai hubungan tingkat pendidikan perawat IGD dengan kepatuhan pelaksanaan standar prosedur operasional penerimaan pasien baru di RSUD AM Paikesit Tenggarong menyatakan bahwa tidak ada hubungan antar kedua variabel tersebut oleh karena sikap pribadi dari perawat tersebut. Hal ini didukung oleh penelitian yang dilakukan Utamy (2015) mengenai hubungan sikap professional dengan kinerja perawat di RS PKU Muhammadiah Yogyakarta didapatkan hasil bahwa terdapat hubungan yang signifikan antar kedua variabel tersebut. Notoadmotjo (2010) mengemukakan bahwa tindakan yang dilakukan oleh seseorang cenderung 
dipengaruhi oleh informasi dan pengetahuan yang diperolehnya. Sikap yang positif terhadap suatu informasi yang diterima oleh seseorang dapat mempengaruhi tindakan yang akan dilakukannya.

Penelitian ini bertentangan dengan penelitian yang dilakukan oleh Sesrianty

\section{SIMPULAN}

Tingkat pendidikan perawat dengan penanganan kejang demam pada anak di IGD RSU GMIM Bethesda Tomohon dan RS Bhayangkara TK III Manado lebih banyak pada kategori baik. Lama masa kerja perawat dengan penanganan kejang demam pada anak di IGD RSU GMIM Bethesda Tomohon dan RS Bhayangkara TK III Manado lebih dari separuh pada kategori baik. Penanganan perawat pada kejang demam anak di IGD RSU GMIM Bethesda Tomohon dan RS Bhayangkara TK III Manado paling banyak pada kategori baik. Tidak terdapat hubungan yang signifikan antara tingkat pendidikan perawat dengan penanganan pertama kejang demam pada anak. Tidak terdapat hubungan yang signifikan antara lama masa kerja perawat dengan penanganana pertama kejang demam pada anak.

Saran bagi institusi keperawatan agar dapat dilakukan pengembangan dan peningkatan keterampilan dalam melaksanakan praktik keperawatan serta melakukan pelatihan khusus untuk menambah wawasan. Saran bagi peneliti selanjutnya yang ingin melakukan penelitian penelitian mengenai penanganan perawat terhadap kejang demam pada anak agar menggunakan metode yang lain seperti observasi secara langsung, menambah jumlah sampel dan memperpanjang waktu penelitian.
(2018) dimana terdapat hubungan antara tingkat pendidikan dengan keterampilan perawat melakukan tindakan bantuan hidup dasar dikarenakan adanya perilaku aktif yang selalu ingin mencari tahu dan terus mempelajari apa yang dikerjakan.

\section{DAFTAR PUSTAKA}

Arifudin, A. (2016). Analisis Faktor Risiko Kejadian Kejang Demam di Ruang Perawatan Anak RSU Anutapura Palu. Journal Kesehatan Tadulako Vol. 2. No. 2, Juli 2016 : 1-72. Jurnal.untad.ac.id/jurnal/index.php/Hea lthyTadulako/article/download/8333/66 14. Diakses pada 16 Agustus, 2019.

Khasana, S. K., (2016). Asuhan keperawatan klien yang mengalami kejang demam dengan hipertermi di RSUD Dr. Soedirman Kebumen. http://elib.stikesmuhgombong.ac.id/621 /1/SITI\%20KHOMISATUN\%20KHA SANAH\%20NIM.\%20A01401966.pdf.

Koesrini, J. (2015). Hubungan Pengetahuan Perawat Tentang Kejang Demam dengan Penanganannya. Https://jurnal.poltekkessoepraoen.ac.id/index.php/HWS/article /view/93/28.

Kusuma, D. 2010. Korelasi antara kadar seng serum dengan bangkitan kejang demam.

http://eprints.undip.ac.id/2906/2/. Diakses pada 06 Agustus 2019.

Lestari, T. (2016). Asuhan keperawatan anak. Yogyakarta : Nuha medika

Makta, L. O. (2013). Pengaruh Motivasi Kerja dengan Kinerja Perawat Pelaksana di Unit Rawat Inap RS Stella Maris Makassar. https://core.ac.uk/download/pdf/25491 276.pdf. Diakses pada 13 Oktober 2019. 
Mamahit V. F. (2015). Hubungan Pengetahuan Perawat dan Dukungan Keluarga dengan Pentalaksanaan Kejang Demam Pada Anak. http://jurnal.unsrittomohon.ac.id/index. php?journal=ejurnal\&page $=$ article $\&$ op =download\&path\%5B\%5D=59\&path $\% 5 \mathrm{~B} \% 5 \mathrm{D}=48$

Manorek, H. (2018). Faktor-faktor yang Berhubungan dengan Penerapan Sasaran Keselamatan Pasien pada Perawat di Ruang Rawat Inap Rumah Sakit Umum Daerah Dr. Sam Ratulangi Tondano. Ejournalhealth.com.

Mawu, D. P., Bidjuni, H., Hamel, R. (2016). Hubungan karakteristik perawat dengan penanganan pertama pada pasien kegawatan muskkuloskeletal di RSUP Prof. Dr. R. D. Kandou Manado.

Mohammadi, M., 2010. Febrile sezures: Four Steps Alogarithmic Clinical Approach Iranian Journal of Pediatrics, volume 20 (No.1), Page 515.

Nazvia, N., A. Loekqijana, dan J. Kurniawati. (2014). Faktor yang Mempengaruhi Kepatuhan Pelaksanaan SOP Asuhan Keperawatan di ICUICCU RSDU Gambiran Kota Kediri. Jurnal Kedokteran Brawijaya 28 (1) Suplemen: 21-25. Diakses pada 10 Oktober 2019.

Notoatmodjo, S. (2010). Metodologi Penelitian Kesehatan. Jakarta : Rineka Cipta.
Putra, H. R., Mulyadi., Ismanto, A. Y. (2014). Hubungan pengetahuan perawat tentang kejang demam dengan penanganan kejang demam pada anak di instalasi gawat rawat darurat anak (IRDA) dan ruang perawatan intensif (RPI) irina $E$ RSUP. Prof. Dr. R. D. Kandou manado.

Renoningsih, D. P. (2016). Faktor-faktor yang Berhubungan dengan Penerapan Patient Safety pada Perawat di Instalasi Rawat Inap Rumah Sakit Umum GMIM Pancaran Kasih Manado. Ejournalhealth.com.

Rizal (2017). Hubungan tingkat pendidikan perawat IGD dengan kepatuhan pelaksanaan standar prosedur operasional penerimaan pasien baru di RSUD AM Paikesit Tenggarong. https://journals.umkt.ac.id/index.php/ji k/article/download/41/23/. Diakses pada 09 Oktober 2019.

Sesrianty, V. (2018). Hubungan Pendidikan dan Masa Kerja dengan Keterampilan Perawat Melakukan Tindakan Bantuan Hidup Dasar. Jurnal Kesehatan Perintis Volume 5 Nomor 2 Tahun 2018.

Utamy, R.T. (2015). Hubungan sikap professional dengan kinerja perawat di RS PKU Muhammadiah Yogyakarta. http://digilib.unisayogya.ac.id/152/2/pu blikasi.pdf. Diakses pada 13 Oktober 2019. 